\author{
ANNA MURIA
}

\title{
Agustí Bartra
}

$\mathrm{D}$

ICESE que el poeta nace, no se hace. Bien, pero nadie realmente ve al poeta en el recién nacido: es tan sólo un ignorado embrión de poeta. La gestación de éste durará años; en el caso de Agustí Bartra, veinticinco por lo menos, los que transcurrieron desde que un nuevo ser humano de ricitos rubios y ojos de un azul clarísimo fue dado a luz en un hogar de la Rambla de Barcelona, muy cerca de las aguas mediterráneas, hasta que él mismo se dio luz como escritor, en 1934. Ya iniciaba la jugosa madurez poética cuando llegó a México. Este fue su segundo nacimiento. El poeta trasterrado nace dos veces. También requiere su tiempo esta nueva gestación: la obra que se ha desarrollado en idóneo paisaje anímico no puede surgir de súbito saturada de otro ambiente y vestida con otro lenguaje. A pesar de que los catalanes tenemos como segundo idioma el castellano, Bartra escritor no había hecho nunca obra de creación más que en su lengua materna. Sin embargo, no tardó muchos años en ceder a la compulsión de crear en español, en mexicano. Su primera obra en este territorio espiritual fue el vasto poema (vastitud de alcance en todos sentidos) concebido por la fascinación del prodigioso mito de Quetzalcoátl, publicado bajo este título, Quetzalcoátl, por el Fondo de Cultura Económica en 1960, libro ya hoy inhallable y en espera de reedición. También directamente en español produjo las obras narrativas Cristo de 200,000 brazos y Démeter, el poema Marsias y Adila, las autobiográficas Elegías de Ecce Homo y la novela de ambiente mexicano La luna muere con agua. A esas producciones se unen, para formar un volumen de trabajo impresionante, las versiones de su obra catalana publicadas en México, sus colaboraciones en la prensa, sus lecturas públicas 
y sus numerosas traducciones de la literatura universal. A toda esa copiosa labor pertenecen las piezas inéditas que ofrecemos en este número de ESTUDIOS: dos disertaciones pronunciadas una en homenaje a León Felipe y otra a Pablo Neruda, y una entrevista que tiene más bien carácter de autobiografía.

Demasiado allegada a él por nuestros cuarenta y tres años de unión, una obligada modestia me impide exteriorizar todos los juicios elogiosos de la obra bartriana que se formulan en la sinceridad de mi hondura, pero sí puedo decir que son indudablemente de notable valor las prendas de su creación que Bartra donó a México. Además de dos hijos hoy también creadores. 